JPPIPA, Vol.2 No.1 2017
Jurnal Penelitian Pendidikan IPA
http://journal.unesa.ac.id/index.php/jppipa

\title{
PENGARUH PEMBELAJARAN MULTIREPRESENTASI BERBANTUAN MULTIMEDIA TERHADAP PERUBAHAN JENIS REPRESENTASI SISWA
}

Oleh:

Susilo

SMK Negeri 1 Kota Mojokerto, Jl. Raya Kedungsari Magersari Mojokerto, Indonesia

\section{Abstrak}

Tujuan utama penelitian ini adalah untuk mengetahui perubahan representasi siswa pada materi optik setelah pembelajaran dengan multirepresentasi berbantuan multimedia. Hasil penelitian menunjukkan bahwa terdapat perubahan jenis dan kualitas representasi. Persentase siswa yang membuat representasi dengan tiga model berubah dari 3,5\% menjadi 47,4\%.

Kata Kunci : multirepresentasi, multimedia, perubahan representasi.

\section{Abstract}

The main purpose of this research is to investigate the increase achievement of concept and the changing of students; representation in optic material after multiple representation learning with multimedia. The results of this research indicated there is a change in the type and quality of the representation. Percentage of students who made the representation with three models changed from $3.5 \%$ to $47.4 \%$.

Keywords: multiplerepresentation, multimedia, changes of representation.

(C) 2017 Universitas Negeri Surabaya

${ }^{1}$ Alamat Korespondensi:

SMKN 1 Mojokerto, Jl. Raya Kedungsari

Magersari, Mojokerto, Indonesia

p-ISSN: $2527-7537$

Email: susiloafir@gmail.com 


\section{PENDAHULUAN}

Mata pelajaran fisika merupakan salah satu aspek dari ilmu pengetahuan alam yang paling mendasar karena berhubungan dengan alam, perilaku dan struktur benda dan untuk memahaminya membutuhkan penalaran dan penjelasan secara mikroskopis (Nelson, 2012). Karena itu, mata pelajaran fisika diajarkan kepada siswa sejak awal. Namun, mayoritas siswa di sekolah menengah mengalami kesulitan dalam mempelajari, memahami, dan menguasai konsep fisika (Purnomo dkk., 2011; Siregar, 2012). Mata pelajaran fisika di Sekolah Menengah Kejuruan (SMK) tidak diujikan dalam ujian nasional, sehingga kurang diminati oleh siswa. Ketidakberminatan siswa dikarenakan kesulitan dalam mempelajari berbagai konsep, teori yang bersifat abstrak, terkesan banyak perumusan dan perhitungan serta guru kurang menunjukkan contoh penerapannya dalam kehidupan sehari-hari (Amirudin, 2010; Nurdin, dkk., 2013).

Berdasar hasil wawancara dengan guru fisika dan pengalaman peneliti, kesulitan siswa adalah dalam menerima pelajaran yang disampaikan guru. Umumnya siswa keliru menghubungkan konsepkonsep sehingga terjadi kesalahan dalam menyelesaikan masalah. Pada materi optik kesulitan siswa meliputi penyelesaian soal yang berbentuk gambar. Siswa hanya menggunakan persamaan matematika tanpa menggambar konsep fisisnya. Kesulitan siswa dalam materi refleksi dan refraksi terutama pada pemahaman konsep, kurang cermat dan teliti dalam perhitungan dan pelukisan jalannya sinar istimewa, letak benda dan bayangan (Yuliana, dkk 2006). Hal ini diperkuat oleh pernyataan Trisnaningsih (2011), di SMAN 1 Semarang kompetensi optik sulit dipahami karena pemahaman siswa sebatas menghafalkan konsep.

Untuk menyelesaikan permasalahan berupa kesulitan siswa dalam menyelesaikan masalah yang berkaitan dengan materi optik tersebut, maka dibutuhkan suatu solusi berupa suatu strategi pembelajaran untuk memudahkan siswa menguasai suatu konsep. Pembelajaran dengan model yang tepat, akan memberikan dampak yang positif dalam kemampuan berfikir dan pemecahan masalah belajar siswa (Nakhas, 2010). Salah satu model yang dapat membantu adalah memberikan representasi-representasi kepada siswa dalam proses pembelajaran. Representasi merupakan sesuatu yang mewakili, menggambarkan atau menyimbulkan obyek, konsep atau proses (Waldrip, 2008). Representasi dalam fisika dapat dilakukan melalui berbagai cara antara lain verbal, gambar, grafik dan matematik (Prain, 2007). Penggunaan representasi dalam pembelajaran fisika dapat meminimalisasi kesulitan siswa dalam belajar fisika dan meningkatkan kualitas pembelajaran IPA (Dolin, 2001; Waldrip, 2008).

Perpaduan dari beberapa representasi disebut sebagai multirepresentasi. Waldrip, dkk (2006) mendefinisikan pembelajaran multirepresentasi sebagai pembelajaran yang memberikan kesempatan luas kepada siswa untuk merepresentasikan kembali (re-representing) konsep yang sama melalui berbagai bentuk atau ragam representasi. Bentuk dan ragam representasi dapat berupa verbal, grafik, tabel, experimental, matematis, figuratif, kinestetik, visual. Multirepresentasi dalam pembelajaran memiliki tiga fungsi utama yaitu sebagai pelengkap, pembatas interpretasi dan membangun pemahaman yang lebih mendalam (Ainsworth, 1999). Melalui pembelajaran dengan multirepresentasi diharapkan siswa dapat menguasai konsep fisika dengan berbagai representasi yang berbeda. Pada penelitian ini, multirepresentasi yang digunakan terdiri dari representasi verbal, representasi gambar, dan representasi matematis, sehingga dalam penyajiannya dapat dibantu dengan media berbasis teknologi komputer yang berupa teks, gambar, atau animasi. Bantuan media digunakan untuk menurunkan anggapan bahwa fisika sebagai pelajaran yang rumit/kompleks dan abstrak sehingga kurang menarik. Kegunaan media dalam proses pembelajaran dapat mempertinggi pemahaman materi dan hasil belajar siswa (Mahardika, dkk 2013; Sutikno, dkk, 2010). Kemudian Arsyad (2011), menyatakan bahwa media pembelajaran dapat membangkitkan motivasi, minat, dan membantu siswa meningkatkan pemahaman dengan mudah, menarik dan terpercaya, serta memadatkan informasi. Bantuan media berbasis komputer yang berupa teks, gambar, dan animasi dikenal dengan multimedia. Selanjutnya yang harus diperhatikan adalah adanya kesesuaian antara semua peralatan dan perlengkapan sekolah dengan tuntutan kurikulum dan materi, metode serta tingkat kemampuan siswa dalam mencapai tujuan pembelajaran (Sutikno, 2010).

Berdasarkan latar belakang permasalahan diatas dan dukungan sarana prasarana di sekolah maka penulis akan melakukan penelitian "Pengaruh pembelajaran multirepresentasi berbantuan multimedia terhadap perubahan representasi siswa". Pembelajaran multirepresentasi yang dalam penyajiannya menggunakan bantuan media flash ini diharapkan dapat menumbuhkan motivasi dan keaktifan siswa dalam pembelajaran, sehingga membuat siswa memiliki penguasaan konsep dengan perubahan jenis dan kualitas representasi yang lebih baik. Secara khusus penelitian ini dirancang untuk mengetahui perubahan representasi siswa dalam 
menyelesaikan soal-soal konsep pemantulan cahaya setelah dilaksanakan pembelajaran multirepresentasi. Dari hasil penelitian ini diharapkan bermanfaat bagi guru dan peneliti yang terlibat baik secara langsung ataupun tidak dalam proses pembelajaran di sekolah.

\section{METODE}

Rancangan penelitian ini menggunakan mixed method dengan desain embedded research design seperti yang dikembangkan oleh Creswell (2007). Desain ini menggabungkan metode kuantitatif dan kualitatif seperti pada Gambar 1.

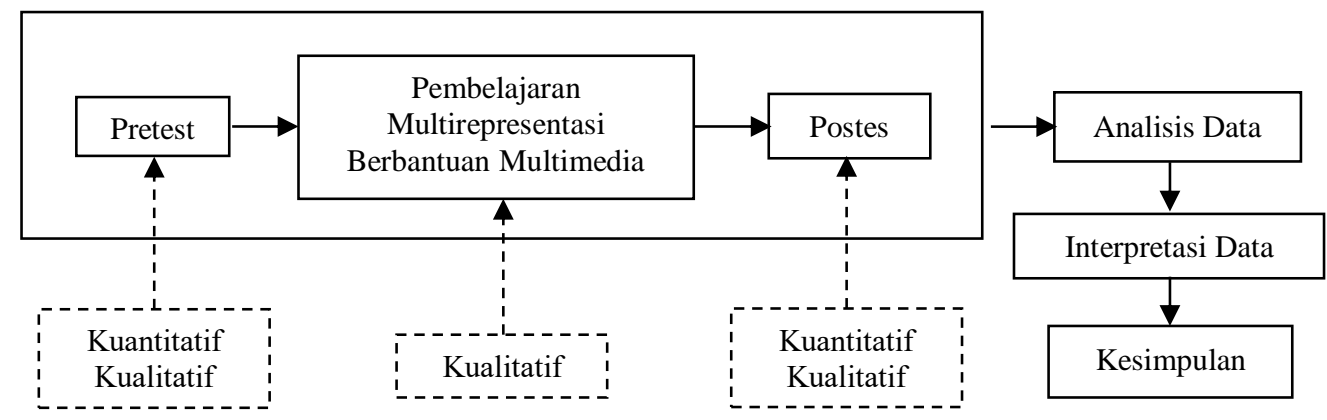

Gambar 1. Embedded Experimental Design (Creswell, 2007)

Gambar 1 diatas menjelaskan penelitian diawali dengan pemberian pretest untuk mengetahui representasi yang digunakan siswa dalam menyelesaikan tes. Hasil pretest dianalisis secara kuantitatif pada jenis representasi. Tahap kedua adalah implementasi pembelajaran pemantulan cahaya dengan multirepresentasi berbantuan multimedia. Perangkat pembelajaran untuk mendukung proses pembelajaran berupa Silabus, RPP dan LKS. Secara garis besar langkah-langkah pembelajaran dilukiskan seperti Gambar 2.

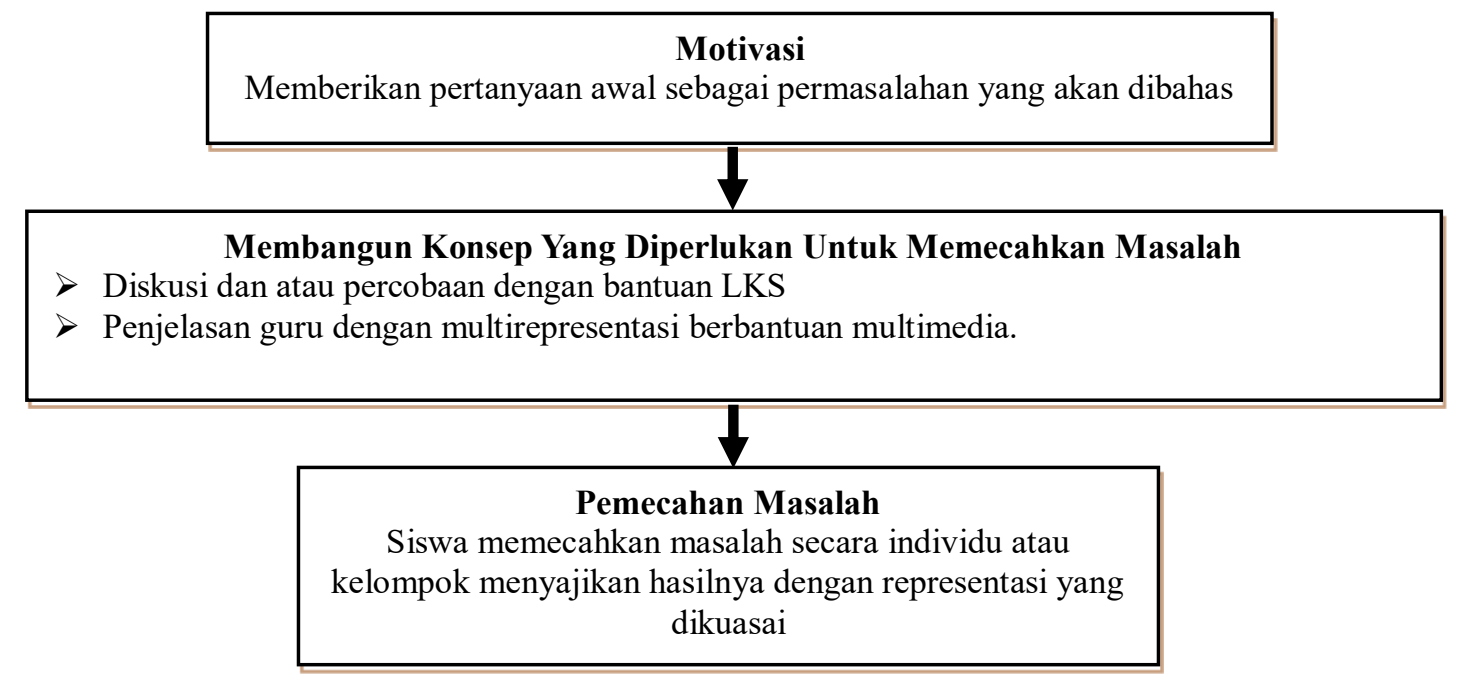

Gambar 2. Langkah-Langkah Setiap Pembelajaran Konsep Pemantulan

Selama kegiatan pembelajaran, dilakukan observasi untuk mengumpulkan data yang digunakan untuk mendiskripsikan pelaksanaan pembelajaran. Observasi dibantu dengan dokumentasi visual dan catatan lapangan. Setelah kegiatan pembelajaran selesai selanjutnya dilaksanakan post test pada hari berikutnya. Hasil post test dianalisis secara kuantitatif untuk melihat perubahan jenis representasi siswa. Jenis representasi yang digunakan siswa dalam menjawab soal diberi kode dengan menggunakan rubrik pengkodean (Tabel 1). Suatu jawaban akan diberi kode menggunakan representasi verbal, matematika, gambar, atau kombinasi dari ketiganya. Sebagai misal, jika jawaban siswa memuat representasi verbal diberikan kode $\mathrm{V}$, dan jika memuat kombinasi antara representasi verbal dan matematika akan dikode VM. Rubrik pengkodean jenis representasi yang dipakai mengadopsi dan memodifikasi milik Sutopo (2013) dan Kohl \& Finkelstein (2006). 
Tabel 1. Rubrik Kode Jenis Representasi Siswa

\begin{tabular}{ll}
\hline Representasi & \multicolumn{1}{c}{ Definisi } \\
\hline Verbal & $\begin{array}{l}\text { Jawaban siswa berbentuk teks yang menggunakan kalimat untuk } \\
\text { mengekspresikan ide atau konsep fisika secara lengkap. }\end{array}$ \\
\hline \multirow{2}{*}{ Matematika } & $\begin{array}{l}\text { Jawaban siswa dalam menyelesaikan masalah terdapat simbol atau persamaan- } \\
\text { persamaan matematika yang berhubungan dengan konsep fisika dan terdapat } \\
\text { langkah-langkah penyelesaian. }\end{array}$ \\
\hline Gambar & $\begin{array}{l}\text { Jawaban siswa terdapat bentuk gambar yang menyajikan informasi-informasi } \\
\text { yang berhubungan dengan konsep dalam fisika atau modifikasi grafik. }\end{array}$ \\
\hline
\end{tabular}

Diadopsi dari Sutopo (2013) dan Kohl \& Finkelstein (2006)

Subjek penelitian adalah siswa kelas XI jurusan Teknik Kendaraan Ringan dengan jumlah siswa sebanyak 19 siswa. Untuk menjawab pertanyaan penelitian, ada dua macam data yang diperlukan, data-data tersebut ada yang bersifat kuantitatif dan ada yang kualitatif.

Tabel 2. Data dan Sumber Data

\begin{tabular}{lllll}
\hline Data & Jenis Data & Sumber Data & $\begin{array}{l}\text { Instrumen } \\
\text { pengumpulan data }\end{array}$ & $\begin{array}{l}\text { Teknik } \\
\text { pengambilan data }\end{array}$ \\
\hline $\begin{array}{l}\text { Proses } \\
\text { pembelajaran }\end{array}$ & Kualitatif & $\begin{array}{l}\text { Interaksi guru } \\
\text { dan siswa }\end{array}$ & $\begin{array}{l}\text { Dokumentasi, dan } \\
\text { catatan di lapangan }\end{array}$ & Observasi \\
\hline $\begin{array}{l}\text { Jenis representasi } \\
\text { yang dibuat siswa }\end{array}$ & Kuantitatif & $\begin{array}{l}\text { Jawaban siswa } \\
\text { pada pretest dan } \\
\text { post test }\end{array}$ & $\begin{array}{l}\text { Tes penguasaan } \\
\text { konsep, rubrik kode. }\end{array}$ & Pretest dan post test \\
\hline
\end{tabular}

\section{HASIL DAN PEMBAHASAN}

Hasil

Hasil dari penelitian ini berupa perubahan jenis representasi yang digunakan siswa dalam menyelesaikan soal. Hasil tersebut disajikan pada Tabel 3 di bawah ini.

Tabel 3. Perubahan jenis representasi yang digunakan siswa dalam menyelesaikan soal

\begin{tabular}{|c|c|c|c|c|c|}
\hline \multirow{2}{*}{ Model } & \multirow{2}{*}{ Jenis Representasi } & \multicolumn{2}{|c|}{ Pretest } & \multicolumn{2}{|c|}{ Post test } \\
\hline & & Jumlah & $\%$ & Jumlah & $\%$ \\
\hline \multirow{3}{*}{ Satu model } & $\mathrm{V}$ & 10 & 17,5 & 1 & 1,8 \\
\hline & M & 0 & 0 & 0 & 0 \\
\hline & G & 20 & 35,1 & 1 & 1,8 \\
\hline \multirow{3}{*}{ Dua model } & VM & 0 & 0 & 2 & 3,5 \\
\hline & VG & 19 & 33,3 & 25 & 43,9 \\
\hline & GM & 2 & 3,5 & 1 & 1,8 \\
\hline Tiga model/Multi & VGM & 2 & 3,5 & 27 & 47,4 \\
\hline Tidak Membuat & - & 4 & 7,0 & 0 & 0 \\
\hline \multicolumn{2}{|c|}{ Jumlah } & 57 & 100 & 57 & 100 \\
\hline
\end{tabular}

Berdasarkan data pada Tabel 2 dapat diketahui bahwa jenis representasi yang dibuat siswa dalam menyelesaikan mengalami perubahan dari pretest ke post test. Dalam penelitian ini secara keseluruhan ada 57 representasi yang dapat dibuat siswa dengan tiga model yaitu satu model, dua model, dan tiga model atau multi. Jumlah dan persentase dari masing-masing jenis representasi yang dibuat siswa dari pretest ke post test mengalami perubahan. Perubahan jenis representasi yang sangat besar terjadi pada kategori tiga model atau multi. Pada saat pretest persentase siswa yang membuat representasi dengan tiga model hanya 3,5\% meningkat menjadi $47,4 \%$ pada post test. Hal ini menunjukkan bahwa terjadi peningkatan jumlah jenis representasi yang dimiliki siswa. Demikian juga pada post test tidak terdapat siswa yang tidak membuat representasi. Jadi dapat disimpulkan bahwa pembelajaran berdampak positif terhadap perubahan jumlah jenis representasi yang dipergunakan siswa untuk menyelesaikan soal.

\section{Pembahasan}


Pembelajaran dengan multirepresentasi tentang konsep pemantulan cahaya meliputi pemantulan pada cermin datar, cekung dan cembung. Pelaksanaan pembelajaran terbagi dalam 2 pertemuan yaitu konsep pemantulan pada cermin datar dan konsep pemantulan pada cermin cekung dan cembung. Melalui pembelajaran tersebut diharapkan siswa mampu menyelesaikan soal-soal yang terkait dengan konsep pemantulan cahaya dengan berbagai representasi. Berdasarkan hasil analisis tes yang ditunjukkan jawaban siswa dan catatan penting selama pembelajaran terdapat perubahan jenis maupun kualitas representasi siswa. Hal ini didukung oleh hasil penelitian Ainsworth (2006), dalam kesimpulannya menyatakan bahwa pembelajaran dengan multirepresentasi meningkatkan penguasaan konsep siswa khususnya materi tekanan dan gerak. Peningkatan penguasaan konsep siswa ini terlihat dengan penambahan representasi-representasi siswa setelah melalui pembelajaran dengan multirepresentasi. Pembelajaran dengan multirepresentasi merupakan pembelajaran yang menggambarkan fenomena fisika dalam berbagai sajian agar lebih mudah dipahami. Sebagaimana dinyatakan oleh Suhandi (2012), bahwa multirepresentasi mempermudah proses analisis dan penjelasan fenomena alam. Prain \& Waldrip (2006) juga menambahkan bahwa penyajian dari representasi ke bentuk representasi yang lain melatihkan keterampilan menerjemahkan dan memahami hubungan konseptual antara representasi.

Pembelajaran multirepresentasi dalam penelitian ini yang dibantu dengan tampilan media flash telah memberikan semangat dan motivasi bagi siswa. Mata pelajaran fisika yang selama ini dikenal abstrak, sulit berubah menjadi menarik. Menariknya pembelajaran ini karena penyajian representasi dapat disajikan secara efektif dan terlihat nyata. Hasil observasi dan catatan penting selama pembelajaran kegiatan dengan menggunakan bantuan media flash ini meningkatkan keaktifan siswa. Hasil penelitian lain juga menyatakan bahwa adanya keaktifan siswa dalam pembelajaran, dan penguatan pengetahuan terhadap informasi dan kemampuan berpartisipasi setelah mengikuti pembelajaran dengan bantuan komputer (Armstrong, 2008; Hrastinski, 2013). Keaktifan siswa dalam belajar merupakan faktor keberhasilan siswa dalam meningkatkan pemahaman dan penguasaan konsep. Hal ini sesuai dengan pernyataan Haviludin (2010), bahwa siswa yang aktif dalam pembelajaran dapat mendukung peningkatan kemampuan siswa dalam menguasai konsep. Lebih lanjut, (Baran, dkk. 2011; Mayo, dkk. 2008) menjelaskan, bahwa adanya kontribusi positif keberhasilan siswa dengan pengajaran visual berbantuan komputer/multimedia pada topik ilmu pengetahuan dan konsep baik ditingkat sekolah menengah dan atas.

Pembelajaran multirepresentasi sangat membantu guru dalam melengkapi konsep dan representasi siswa yang sudah dimiliki sebelumnya. Pembelajaran dengan multirepresentasi dilakukan untuk mengorganisasi konsep yang sudah dimiliki siswa. Konsep awal siswa diperoleh sebagai hasil dari interpretasi atas pengamatan terhadap fenomena di sekitarnya. Dalam penelitian ini multirepresentasi telah membantu siswa dalam memahami dan menguasai konsep pemantulan secara mendalam. Siswa dapat menghubungkan representasinya yang sudah didapatkan di SMP. Hal ini sesuai dengan pernyataan bahwa dalam berpikir siswa mengolah, mengorganisasikan bagian-bagian dari pengetahuannya sehingga pengalaman dan pengetahuannya tersusun kembali sehingga dapat dipahami dan dikuasai (Dwijananti \& Yulianti, 2010). Sutopo (2013) juga menyatakan bahwa multirepresentasi membantu siswa memahami secara mendalam melalui informasi yang terintegrasi.

Hasil analisis jawaban siswa dalam mengerjakan soal ditemukan bahwa jenis dan kualitas representasi mengalami peningkatan. Siswa telah mampu menyelesaikan soal dengan mengkombinasikan beberapa representasi. Siswa sudah mampu menghubungkan representasi satu sama lain, menterjemahkan soal dalam bentuk gambar maupun sebaliknya. Peningkatan representasi siswa lebih disebabkan aktifnya siswa dalam kegiatan pembelajaran. Selama pembelajaran berlangsung siswa termotivasi dan secara aktif terlibat dalam kegiatan pembelajaran. Berdasarkan hasil observasi dan catatan penting selama pembelajaran. Siswa aktif dan antusias dalam memahami konsep melalui kegiatan percobaan dan penyajian representasi-representasi yang dicontohkan guru. Pembelajaran yang aktif merupakan pembelajaran yang melibatkan siswa secara penuh dalam pelaksanaan pembelajaran (Asmani, 2009:64).

Dalam penelitian ini bantuan media dalam kegiatan pembelajaran juga memberi dampak yang sangat positif untuk meningkatkan motivasi siswa dalam belajar. Penyajian konsep abstrak menjadi lebih mudah dipahami siswa dengan penyajian representasi yang nyata dalam animasi media flash. Sebagian besar siswa mampu menerima dengan baik pemahaman konsep dengan bantuan media tersebut. Berdasarkan hasil pengamatan dan catatan penting selama pembelajaran siswa tidak mengalami kesulitan ketika materi disajikan dalam media flash. Hal ini sesuai dengan pernyataan Mahardika, dkk (2013), Sutikno, dkk, (2010) bahwa penggunaan media dalam proses pembelajaran dapat mempertinggi pemahaman materi dan hasil 
belajar siswa. Arsyad (2011), juga mengatakan bahwa media pembelajaran dapat membangkitkan motivasi dan minat siswa, serta dapat membantu siswa meningkatkan pemahaman, menyajikan data dengan menarik dan terpercaya, memudahkan penafsiran data, dan memadatkan informasi.

Temuan lain dari hasil analisis tiap butir soal persentase kesalahan siswa dalam membuat representasi matematis dan gambar menurun. Hasil analisis penyelesaian soal pada pretest banyak kesulitan yang dialami siswa. Sebagian besar siswa tidak dapat menyelesaikan soal yang harus menggunakan representasi matematis dan gambar. Hasil penelitian lain di SMAN Semarang juga menyatakan, bahwa kompetensi optik sulit dipahami karena pemahaman siswa sebatas menghafalkan konsep (Trisnaningsih, 2011). Yuliana, dkk, (2006) menambahkan, siswa kesulitan dalam materi refleksi dan refraksi terutama pada pemahaman konsep, kurang cermat dan teliti dalam perhitungan dan pelukisan jalannya sinar-sinar istimewa, letak benda dan bayangan dalam gambar. Namun setelah dilaksanakan pembelajaran multirepresentasi siswa mendapatkan motivasi dan merasa tertarik untuk dapat memahami konsep. Sebagian besar siswa telah mampu mengaitkan representasi satu dengan representasi yang lain. Terdapat siswa yang sudah mampu menyelesaikan soal yang berbentuk gambar, pelukisan jalannya sinar pada pembentukan bayangan pada posttest berdasar representasi matematis yang dibuat sebelumnya atau sebaliknya. Penggunaan beberapa representasi inilah yang mengurangi kesalahan siswa dalam menyelesaikan soal. Hal ini sejalan dengan pernyataan Sutopo (2013), bahwa multirepresentasi dapat membantu siswa dengan menggunakan representasi yang mudah dipahami, seperti grafik, gambar yang dapat menuntun dalam menginterpretasi ekuitas.

Berdasarkan catatan penting hasil tanya jawab singkat, siswa menyatakan bahwa dengan pembelajaran multirepresentasi siswa dapat memahami kesulitan dalam menggunakan sebuah representasi. Memahami kesulitan membuat siswa termotivasi untuk menghubungkan representasi satu dengan bentuk representasi yang lain. Siswa juga menyatakan mendapatkan banyak pilihan representasi untuk bisa menyelesaikan suatau soal Dalam hal ini siswa menyatakan senang dengan representasi berbentuk gambar. Hasil analisis penyelesaian soal pada pretest dan post test juga menunjukkan bahwa mayoritas siswa menggunakan representasi gambar.

\section{PENUTUP}

Berdasarkan temuan-temuan hasil penelitian dapat disimpulkan bahwa terdapat peningkatan kemampuan representasi siswa. Peningkatan kemampuan siswa terlihat dari perubahan jenis, model, dan kategori kualitas representasi yang dibuat siswa dalam memecahkan soal. Jenis representasi yang dibuat siswa pada saat pretes tergolong satu model dan 2 model, namun pada postes mayoritas sudah tiga model. Pada saat pretes persentase jumlah siswa yang membuat representasi dengan tiga model hanya 3,5\% meningkat menjadi $47,4 \%$.

Beberapa saran diajukan berkenaan dengan hasil penelitian ini. Bagi guru, pertama hendaknya guru dapat menerjemahkan representasi yang sulit dipahami siswa dan memberikan contoh bentuk representasi yang mudah dipahami siswa. Hasil penterjemahan representasi siswa dapat digunakan sebagai dasar untuk mempelajari konsep berikutnya. Kedua, hendaknya guru melakukan penilaian terhadap kemampuan siswa melalui tes atau evaluasi dan apabila masih ditemukan siswa yang melukan kesalahan maka perlu dilakukan pembahasan permasalahan agar tidak terjadi kesalahan konsep yang berulang. Bagi peneliti pendidikan fisika lainnya, sebaiknya dilakukan wawancara dengan pertanyaan yang detail dan menggunakan observer yang cukup sesuai kebutuhan disertai dengan lembar observasi yang jelas.

\section{DAFTAR PUSTAKA}

Ainsworth, S. 1999. The Functions of Multiple Representations. Computers \& Education, 33, 131-152.

Amirudin, S.S. 2010. Sistem pembelajaran berbasis LTSA materi gelombang dan sifat-sifatnya dengan metode problem solving. Jurnal Teknologi Informasi. Vol. 6, No. 1, April 2010.

Armstrong, K., \& Retterer, O. 2008. Blogging as L2 writing: A case study. Association for the Advancement of Computing In Education Journal. Vol. 16 No. 3, 233-251.

Arsyad, A. 2007. Media Pembelajaran.Jakarta: Raja Grafindo Persada.

Asmani, J.M., 2009. Jurus-jurus Belajar Efektif untuk SMP dan SMA. Yogyakarta: Diva Press.

Bakac, M., Tasoglu, A.K., \& Akbay, T. 2011. The effect of computer assisted instruction with simulation in science and physics activities on the succes of student electric current. Eurasian Journal of Physics and Chemistry Education. 34-42. 2011.

Baran, M., Tasoglu, A.K., \& Akbay, T. 2011. Research on the effect of certain variables chosen and technology-supported projectbased learning approach on 11 th-grade students attitudes toward computers. 
Eurasian Journal of Physics and chemistry Education. 1-13, 2011.

Cresswell, J. W., \& Clark, V.L.P., 2007. Desinging and conducting mixed methods research. California: Sage Publications.

Dolin, J. 2001. Representational forms in physics. In D. Psillos, P. Kariotoglou, V.

Tselfes, G. Bisdikian, G. Fassoulopoulos, E. Hatzikraniotis, E. Kallery (Eds.). Science education research in the knowledge-based society. Proceedings of the Third International Conference (pp. 359-361). Thessaloniki, Greece: Aristotle University of Thessaloniki.

Dimyati \& Mudjiono. 1999. Belajar dan Pembelajaran. Jakarta: PT Rineka Cipta.

Druxes, H., Born G., Siemsen F. 1983. Kompedium Didaktik Physik. Munchen: Ehrenwirth.

Etkina, E., dkk. 2006. Scientific abilities and their assesment. Physics Education Reserch, 2(2) : $1-15$.

Goldin, G. A. 2002. Representation in mathematical learning ang problem solving dalam International Research in Mathematical Educatinon. L.D. English. pp. 197-218. New Jersey: Lawrence Erlbaum Associates.

Guzel, B. Y. \& E. Adadan. 2013. Use of multiple representations in developing preservice chemistry teachers' understanding of the structure of matter. Journal of Environmental \& Science Education. Vol. 8, No. 1, 109-130 Januari 2013.

Hake, R. R. 1998. Interactive-engagement versus traditional methods: A six-thousand-student survey of mechanics test data for introduc $\neg$ tory physics courses. American Journal of Physics. 66 (1): 64-74.

Hamalik, O. 1994. Media Pendidikan . Bandung: PT Citra Aditya Bakti

Haviludin. 2010. Active learning berbasis teknologi informasi. Jurnal Informatika Mulawarman. Vol. 5, No 3, 28-31 September 2010.

Hrastinski, S., \& Monstad, T. 2013. Exploring the relationship between the use of an interactive video website and organizational learning. Sage Publications.

Hwang, W.Y., Chen, N.S., Dung, J.J., \& Yang, Y.L. 2007. Multiple representation skills and creativity effects on mathematical Problem solving using a multimedia whiteboard system. International Forum of Educational Technology \& Society. 10 (2), 191-212.

Keles, O., \& Ozsoy, S. 2009. Pre-service teacher's attitudes toward use of vee diagrams in general physics laboratory. International
Electronic Journal of Elementary Education. 14 (1), 124-140.

Kohl, P.B. \& Finkelstein, N.D. 2006. Effect of instructional environment on physics students' representation skills. Physical Review Special Topic - Physics Education Research. 2, 010102.

Kohl, P.B. \& Finkelstein, N.D. 2008. Patterns of multiple representation use by experts and novices during physics problem solving. Physical Review Special Topic - Physics Education Research. 4, 010111.

Lesh, R., Post, T., \& Behr, M. 1987. Representations and translations among representations in mathematics learning and problem solving dalam Problems of Representations in the Teaching and Learning of Mathematics C. Janvier, (Ed.) (pp. 33-40). Hillsdale, NJ: Lawrence Erlbaum.

Mahardika, K.I., Albertus, D.L., \& Wahyu, R. 2013. Penerapan model pembelajaran kooperatif tipe STAD disertai media audovisual terhadap kemampuan multirepresentasi fisika siswa SMP. Jurnal Pendidikan Fisika. Vo. 2 No. 3, hal 315 320, Desember 2013.

Mayo, A., Sharma, M., \& Muller, D. 2008. Qualitative differences between learning environments using videos in small groups whole class discussions: A prelimenary study in physics. Research in Science Education.

Miles, M.B. \& Huberman, A.M. 1984. Qualitative data analysis: A sourcebook of new methods. California; SAGE publications Inc.

Morgan, G.A. Leech, L.N., Gloeckner, W.G., \& Barret, C.K. 2005. SPSS For Intermediate Statistics Use and Interpretation. New Jersey: Lawrence Erlbaum Associates.

Nakhas, S. 2010. Pengaruh strategi pembelajaran berbasis masalah berbantuan komputer terhadap penguasaan konsep fisika ditinjau dari kemampuan berfikir spasial siswa SMA. Tesis tidak diterbitkan. Malang: PPs UM.

Nelson, R. Q., Isaac B., \& De-Graft K.O. 2012. Impact of audio-visual aids on senior high school students achievement in physics. Eurasian Journal of Physics and chemistry Education. Vol. 4, No. 1, hal. 46-54, 2012.

Nurdin, Jurubahasa, S., \& Ratelit, T. 2013. Pemanfaatan sumber belajar berbasis contextual teaching and learning dalam upaya peningkatan kualitas pembelajaran fisika umum I. Jurnal Pendidikan Fisika Indonesia. Vol. 9. Januari 2013. 
Prain, V. 2007. “An exploratory study of teachers' perspectives about using multi-modal representations of concepts to enhance science learning". Canadian Journal of Science, Mathematics and Technology Education.

Purnomo, T. H., Sugiyanto, \& Akhlis, I. 2011. Educational computer game materi listrik dinamis sebagai media pembelajaran fisika untuk siswa SMA. Jurnal Pendidikan Fisika Indonesia. 7 (2011): 121-127.

Rosengrant, D., Etkina, E., \& Heuvelen, A.V. 2006. An Overview of Recent Research on Multiple Representations. New Jersey: The State University of New Jersey.

Sadiman \& Sundahri. 2003. Aplikasi Pengalaman Edgar Dale dalam Proses Belajar Mengajar pada Mata Kuliah Dasar-Dasar Teknologi Benih. Pancaran Pendidikan, XVI (56): 8085.

Siregar, F.A. 2012. Pengaruh model kooperatif tipe NHT terhadap hasil belajar siswa kelas VIII SMPN 18 Medan. Jurnal Pendidikan Fisika. Vol. 1, No. 1 : 33-38, Juni 2012.

Sudirman. 2006. Fisika 3 Untuk SMK dan MAK Kelompok Teknologi dan Kesehatan. Jakarta: Penerbit Erlangga.

Sudjana, N. 2000. Dasar-Dasar Proses Belajar Mengajar. Bandung: Sinar Baru Algesindo.

Suhandi A., \& Wibowo, F.C. 2012. Pendekatan multirepresentasi dalam pembelajaran usaha energi dan dampak terhadap pemahaman konsep mahasiswa. Jurnal Pendidikan Fisika Indonesia. 8, 1-7, (2012).

Suparno, P. 2013. Miskonsepsi dan Perubahan Konsep Dalam Pendidikan Fisika. Jakarta : PT Grasindo.
Sutikno, Wahyudin, \& Isa A. 2010. Keefektifan pembelajaran berbantuan multimedia menggunakan metode inkuiri terbimbing untuk minat dan pemahaman siswa. Jurnal Pendidikan Fisika Indonesia. Vol. 6, No. 1, 58-62, (2010).

Sutopo, Liliasari, Waldrip, B, \& Rusdiana D. 2012. Impact of representasional approach on the improvement of students understanding of acceleration. Jurnal Pendidikan Fisika Indonesia. 8, 61-173, (2012).

Sutopo. 2013. Improving students' representational skill and generic science skill using representational approach. Jurnal Ilmu Pendidikan. Vol. 19, No 1 (2013).

Trisnaningsih. 2011. Upaya peningkatan aktifitas siswa kelas $\mathrm{X}$ semester II SMAN 1 semarang dengan menerapkan perangkat pembelajaran bervisi SETS. Jurnal Pendidikan Fisika Indonesia. Vol. 2 No. 1 April 2011.

Waldrip, B., Prain, V. \& Carolan, J. 2006. Learning junior secondary sience through multimodal representation. E-Journal of Science Education, 11 (1), 87-107.

Waldrip, B. 2008. Improving learning through use of representations in science. Proceeding The 2nd International Seminar on Science Education. Science Education Program. Bandung: Graduate School Indonesia University of Education.

Yuliana, S., Aji S., \& Siti K. 2006. Rancang bangun "multi board" sebagai alat peraga baru dalam pembelajaran trigonometri, optik geometri dan vektor. Jurnal Pendidikan Fisika Indonesia, Vol. 4, No. 2, Juli 2006. 